\section{EPA firm on pesticides ban}

\section{from Colin Norman, Washington}

Russell Train, Administrator of the Environmental Protection Agency, last week held firm on his decision to halt production of the widely used pesticides aldrin and dieldrin, pending the outcome of public hearings on charges that the chemicals may be carcinogenic to man.

The decision is an attempt to establish an important concept in the regulation of environmental chemicals -that possibly dangerous substances should be removed from the market until they are found to be safe, rather than being kept in use until they are definitely found to be hazardous.

That concept is already well established in the regulation of food additives in the United States, thanks to a legal requirement that chemicals cannot be added to food if they are found to increase the incidence of cancer in test animals, but attempts to apply it to the regulation of other environmental chemicals have so far met with mixed

AFTER the good news about Drumbuie, the bad news about Kishorn. The Secretary of State for Scotland, Mr William Ross, has approved an application by the Howard/Doris partnership to build concrete gravitytype oil production platforms at the Loch (pictured). On the face of it the Kishorn site seems to satisfy none of Mr Ross's criteria for a suitable site; that it must have access to existing facilities, that it can draw on existing labour sources and that it can make use of existing infrastructure.

By giving this decision $\mathrm{Mr}$ Ross has brought down on himself a hail of criticism, not only from those who successfully opposed the development at Drumbuie, but also from those who felt that Drumibuie would be the lesser of two evils. As the site is even more remote than Drumbuie from existing rail and road services, all materials and supplies are to be shipped across the loch from the nearest rail link, which will involve an additional development at this point.

But giving his reasons for the decision, Mr Ross emphasised that the very remoteness of the site was a point in its favour. Also, the site will employ a smaller workforce than that proposed at Drumbuie. Obviously a major factor in the differing decisions is the National Trust land involved at Drumbuie, and the fact that far fewer local residents were likely to be affected. success. Moves against aldrin and dieldrin were made by the EPA as long ago as 1971, when the agency issued an order to cancel the pesticides' registration-which was tantamount to banning their use. That order was based on findings that the pesticides increase the incidence of liver tumours in mice when fed to them in relatively high doses. But the Shell Chemical Corporation, sole manufacturers of aldrin and dieldrin, appealed against the order, and the appeal has been making glacial progress through the courts and EPA's administrative machinery ever since.

Meanwhile, evidence has accumulated that aldrin and dieldrin raise a variety of tumours in at least five strains of mice and possibly rats as well. Their residues can be found in the tissues of virtually every man, woman and child in the United States, and a survey conducted last year by the Food and Drug Administration found the pesticides in $83 \%$ all dairy products, $88 \%$ of garden fruits, and $96 \%$ of meat, poultry and fish.

On the basis of that evidence, EPA privately asked Shell to stop producing aldrin and dieldrin, at least until the

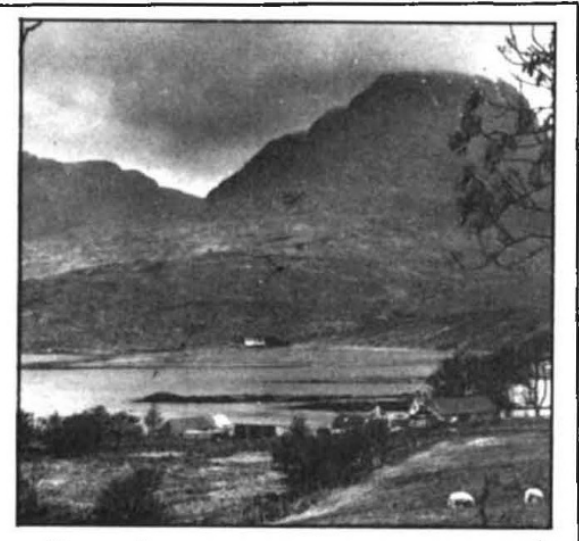

But what must worry many people is the fear that this is only the beginning. This decision has been made despite the recent publication of the Scottish Development Department's Coastal Planning guidelines which designate the West Highlands coast as a conservation zone. Mowlem/ Taylor Woodrow who lost the site at Drumbuie, are unlikely to rest under this decision and will no doubt look for a site nearby. As necessary infrastructure is developed, the economic advantages of allowing more sites to use it will no doubt be cited.

A few crumbs of comfort may be gathered in the appendices to the Secretary of State's memorandum. Twelve years from now, the site must be cleared completely of all buildings, and restored to its original condition, with replanting if necessary. Optimists can book their holiday now. appeals process on the cancellation order has been exhausted. But Shell refused, and announced that it would produce about 10 million pounds of the pesticides this Autumn for use in 1975, knowing full well that if EPA's cancellation order is upheld next year it would be virtually impossible to call in the pesticides which had already been sold. Train therefore excrcised emergency authority in July to order Shell to stop making the pesticides. Shell appealed against that ruling, however, and demanded a public hearing on the matter. The hearing took place in August and early September before Administrative Law Judge Herbert L. Perlman, who upheld Train's order on September 20 , as a result of which Train last week refused to reconsider his decision. Shell officials immediately announced that they will take their case to the federal courts.

There is no dispute over the fact that aldrin and dieldrin increase the incidence of liver tumours in mice-in fact, Shell representatives even conceded that point during the public hearings-but there is a dispute over the relevance of that fact for humans.

According to $\mathrm{Dr}$ Don Stevenson, Director of Shell's Tunstall Laboratory, for example, five separate criteria must be met before there is sufficient evidence of human carcinogenicity. There must be a higher incidence of tumours in exposed animals, tumours should develop in more than one species, there is adequate proof that the development of the tumours is related to the test compound, the animal has proved to be an adequate model for extrapolating to man, and that there is proof of at least one incidence of cancer in man related to the test compound.

As Train pointed out last wack. such criteria would be impossible to meet since cancer in man often takes several decades to develop after the initial exposure. Both Perlman and Train therefore concluded that there is already sufficient evidence of carcinogenicity in mice to suggest that aldrin and dieldrin pose a high risk to man.

Meanwhile, the appeals process for E.PA's original cancellation order against the pesticides grinds on. Public hearings have been dragging on since August 1973, and according to Train, they will continue into the "indefinite future". It is worth noting, however, that although the production han in theory does not prejudge the cancellation issue, Perlman is sitting as hearing cxaminer for the cancellation hearings as well as for the hearings into the production ban. IIs 109-page opinion on EPA's production ban represents such a severe indictment of the pesticides that it seems unlikely that he will ultimately give them a clean bill of health. 